\title{
Microwave Assisted Liberation of High Phosphorus Oolitic Iron Ore
}

\author{
Mamdouh Omran',2*, Timo Fabritius'1, Nagui Abdel-Khalek², Mortada El-Aref ${ }^{3}$, \\ Abd El-Hamid Elmanawi ${ }^{3}$, Mahmoud Nasr ${ }^{2}$, Ahmed Elmahdy ${ }^{2}$ \\ ${ }^{1}$ Laboratory of Process Metallurgy Research Group, Process and Environmental Engineering Department, \\ University of Oulu, Oulu, Finland \\ ${ }^{2}$ Central Metallurgical Research and Development Institute, Cairo, Egypt \\ ${ }^{3}$ Geology Department, Faculty of Science, Cairo University, Cairo, Egypt \\ Email: * Mamdouh.omran@oulu.fi
}

Received 15 July 2014; revised 21 August 2014; accepted 2 September 2014

Copyright (C) 2014 by authors and Scientific Research Publishing Inc.

This work is licensed under the Creative Commons Attribution International License (CC BY).

http://creativecommons.org/licenses/by/4.0/

(c) (i) Open Access

\section{Abstract}

The influence of microwave treatment on the liberation of iron ore from the high phosphorus oolitic iron ore from Aswan region, Egypt was studied. The effect of microwave power, exposure time and grain size on the liberation of iron ore was investigated. The microfractures and cracks of the samples were characterized before and after microwave treatments. The heating rate of high phosphorus oolitic iron ore was studied. Crystallinity of hematite was characterized before and after microwave pretreatment. The results indicated that intergranular fractures formed between the gangues (fluorapatite and chamosite) and hematite after microwave treatment, leading to improved liberation of iron ore and a significant reduction in comminution energy. Percentages of fraction $\leq-0.125 \mathrm{~mm}$ increased from $46.6 \%$ to $59.76 \%$ with increased exposure time from 0 to 60 seconds. The heating rate of iron ore showed that microwave treatment was less efficient at smaller particle sizes for a fixed applied power density. Crystallinity of hematite increased with the microwave exposure time.

\section{Keywords}

Microwave Treatment, High Phosphorus Oolitic Iron Ore, Liberation

\section{Introduction}

Ironstones may (or may not) contain $>50 \%$ ooids and pisoids. Ooids are spherical or ellipsoidal coated-grains

${ }^{*}$ Corresponding author.

How to cite this paper: Omran, M., Fabritius, T., Abdel-Khalek, N., El-Aref, M., Elmanawi, A.E.-H., Nasr, M. and Elmahdy, A. (2014) Microwave Assisted Liberation of High Phosphorus Oolitic Iron Ore. Journal of Minerals and Materials Characterization and Engineering, 2, 414-427. http://dx.doi.org/10.4236/jmmce.2014.25046 
smaller than $<2 \mathrm{~mm}$ in diameter, which display regular concentric laminae surrounding a central core. Grains similar to ooids, but larger than $>2 \mathrm{~mm}$ are known as pisoids [1]. The oolitic iron ores are widely spread worldwide, some of which have huge reserves, for instance, Wadi Fatima mine in Saudi Arabia [2], Lorraine mine in France [3], Bell island mine in Canada [4], Dilband mine in Pakistan [5], Xuanhua region in China [6] and Aswan region in Egypt [7] [8].

The main obstacle for using these deposits is the fine dissemination of silica and aluminum minerals and especially the high level of phosphorus content. This difficulty is mainly due to the poor liberation of iron minerals from oolitic gangues. Song et al. [9] observed that fine grinding (commonly 1 - $5 \mu \mathrm{m}$ ) required liberating iron minerals from associated gangue minerals. Such fine particles are very difficult to be beneficiated via conventional processes of mineral processing (e.g. flotation and magnetic separation).

Phosphorus removal from the high phosphorus oolitic iron ores has been investigated by several processes, including a) selective flocculation-reverse flotation [10], b) chemical leaching [11] [12], c) microbiological method (bioleaching) [13] [14], and d) metallurgical method (magnetization roasting and reduction) [15] [16]. Although some of these methods achieve the purpose of phosphorus removal, there still have disadvantages for instance low efficiency of dephosphorization, relatively high cost, and low iron recovery.

The development of a successful and economic process to remove phosphorus from the high phosphorus iron ores would significantly extend the reserves of high grade low phosphorus iron ores [17]. There are two main challenges in mineral comminution: energy consumption and mineral recovery [18]. About $1.5 \%$ - 2\% of the total national energy consumption in the industrial mining countries is attributed to comminution [19]. Wang et al. [20] suggested that there are two main reasons for investigating liberation improvement: a) liberation of particles at large size reduces the energy consumption during grinding, and b) very fine grain size is very difficult in physical separation processes and consumes more grinding energy. Liberation at coarse grain size is suitable for physical separation techniques, such as flotation or magnetic separation. So that it is very crucial to focus on techniques that help in particles liberation with minimum power consumption and particle size reduction. Microwave treatment of ores is considered as a potential way for reducing the grinding energy consumption and increasing the liberation and recovery of valuable minerals [21].

Microwave energy is a non-ionizing electromagnetic radiation with frequencies in the range of $300 \mathrm{MHz}$ to $300 \mathrm{GHz}$. Microwave frequencies include three bands: the ultra high frequency (UHF: $300 \mathrm{MHz}$ to $3 \mathrm{GHz}$ ), the super high frequency (SHF: $3 \mathrm{GHz}$ to $30 \mathrm{GHz}$ ) and the extremely high frequency (EHF: $30 \mathrm{GHz}$ to $300 \mathrm{GHz}$ ) [22] [23].

Microwave treatment improves the liberation of high phosphorus oolitic iron ores through generating intergranular fractures in oolitic iron ores [9]. The difference in the absorption of microwave energy, thermal expansion and dielectric properties of iron and gangue minerals leads to generating intergranular fractures between iron and gangue minerals [24]-[28]. High phosphorus oolitic iron ores are usually composed of hematite, dolomite, clinochlore, quartz and apatite (fluorapatite or hydroxyl fluorapatite). Microwave radiations have significant influence on the microstructure of the oolitic units [16]. Hematite, phosphorite, silicate minerals and other gangues in the ore differ in absorbing microwave energy. These minerals have different thermal expansion and thus thermal stresses are generated on the boundaries among them. When these thermal stresses reach a certain level, cracks and fissures are formed at the boundaries [29]. Jones et al. [24] stated that after microwave radiation, intergranular fractures occur around the grain boundaries between absorbent and transparent phases. Amankwah et al. [30] observed that differential heating of different minerals phases in an ore results in thermal stress cracking, which makes the ore more amenable to size reduction and results in a decrease in the work index.

Kingman et al. [31] [32] studied the influence of microwave radiation on Norwegian ilmenite ores. It was concluded that short, high-power treatments were most effective and led to a reduction in work index of up to $90 \%$ and increased recovery of ilmenite, due to the improvement of liberation and magnetic properties of ilmenite ores after microwave treatment. The influence of mineralogy on the responses of ores to microwave radiation was studied by Kingman et al. [33]. They concluded that samples with a mixture of "good heaters" in a lattice of "poor heaters" consisting of coarse grain size gave the best response and greatest reduction in work index after microwave treatment. Poorest response could be expected from ores containing highly disseminated, fine-grained minerals.

The aim of this study was to investigate the effect of microwave pretreatment on liberation of iron bearing minerals from phosphorus and other gangues minerals. The effect of different parameters such as microwave power, exposure time and grain size of particles on the heating rate, crystallinity and intergranular fractures of oolitic iron ore will be studied. 


\section{Experimental and Analytical Methods}

\subsection{Iron Ore Sample}

The high phosphorous oolitic iron ore used in this study was collected from Aswan region, Egypt. The east of Aswan area represents the main occurrence of the Cretaceous oolitic ironstone bands of South Egypt which are confined to clastic successions belonging to the "Nubian" sandstones or "Nubia facies" [7]. Figure 1 and Table 1 show the XRD pattern and chemical analysis, respectively, of iron ore used in the tests.

\subsection{Microwave Treatment}

The samples were treated using a $2.45 \mathrm{GHz}$ microwave oven (sandstorm, model S25CSS11E and cavity dimension $513 \mathrm{~mm}(\mathrm{D}) \times 482 \mathrm{~mm}(\mathrm{~W}) \times 310 \mathrm{~mm}(\mathrm{H})$ ) with a maximum output power of $900 \mathrm{~W}$. Iron ore samples were treated in the oven for varying exposure times and power densities. Samples were allowed to cool in the microwave oven to room temperature.

Table 1. Chemical composition of high phosphorus oolitic iron ore.

\begin{tabular}{cc}
\hline Oxides & Weight \% \\
$\mathrm{Fe}_{2} \mathrm{O}_{3}$ & 74.96 \\
$\mathrm{SiO}_{2}$ & 7.48 \\
$\mathrm{P}_{2} \mathrm{O}_{5}$ & 3.24 \\
$\mathrm{CaO}$ & 5.44 \\
$\mathrm{Al}_{2} \mathrm{O}_{3}$ & 4.47 \\
$\mathrm{MnO}$ & 0.54 \\
$\mathrm{MgO}$ & 1.26 \\
$\mathrm{Na}_{2} \mathrm{O}$ & 0.37 \\
$\mathrm{~K}_{2} \mathrm{O}$ & 0.05 \\
$\mathrm{~F}$ & 0.19
\end{tabular}

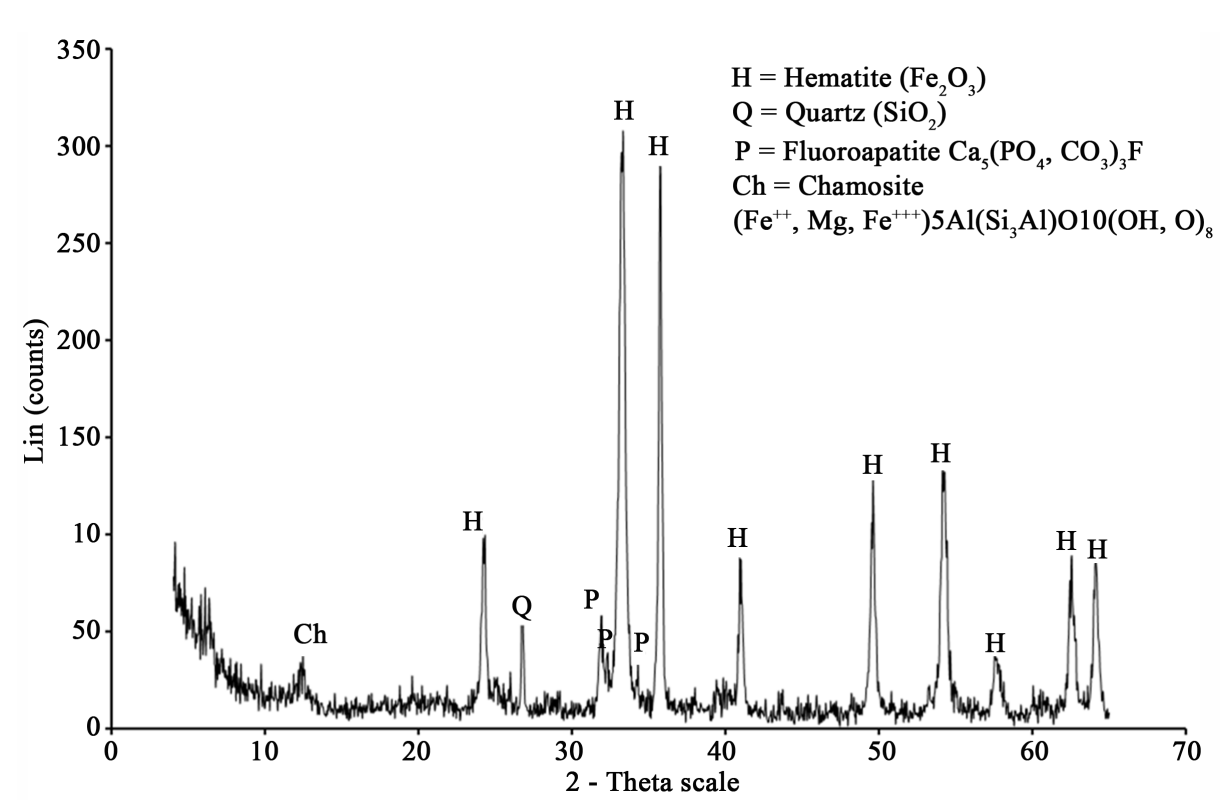

Figure 1. X-ray diffraction chart for high phosphorus oolitic iron ore. 


\subsection{Analytical Methods}

\subsubsection{X-Ray Diffraction (XRD)}

The bulk mineralogical composition and crystallinity of the iron ore were performed on powdered samples using Siemens D5000 XRD powder diffractometer. The device contains a $\mathrm{Cu} \mathrm{K} \alpha$ radiation with a graphite monochromator. The XRD analyses were done using $40 \mathrm{KV}$ and $40 \mathrm{~mA}$.

\subsubsection{X-Ray Fluorescence (XRF)}

Chemical analyses were performed on whole rock powders by X-ray fluorescence (Bruker AXS S4 Pioneer). The major elements were determined on fused beads (glass disks) in order to minimize matrix effects.

\subsubsection{Scanning Electron Microscope (SEM)}

The micro-morphological characteristics of the iron ore before and after treatment with microwave were investigated using Zeiss ULTRA plus field emission scanning electron microscope (FESEM) attached to an Energydispersive X-ray spectroscopy (EDS) unit for chemical analysis.

\subsubsection{Electron Probe Microanalyses (EPMA)}

The mineral chemistry of the iron minerals and the element distribution maps within oolites and interstitial spaces between the ferruginous oolites were determined by Electron Probe Microanalyses (EPMA). The EPMA were performed on a Jeol JXA-8200 device with WDS/EDS microanalyzer.

The XRD, XRF, SEM and EPMA analyses were carried out at the Center of microscopy and nanotechnology, University of Oulu, Finland.

\section{Results and Discussion}

\subsection{Mineralogy and Chemistry of the High Phosphorous Oolitic Iron Ore}

According to El Sharkawi et al. [7] the true oolitic ironstone of Aswan region consists entirely of closely spaced (grain-supported) ferruginous ooids (>95\%) with less abundant detrital quartz grains, kaolinitic rock fragments and ferruginous clayey materials "chamosite" $(<5 \%)$. Ooids are spherical or ellipsoidal coated-grains $<2 \mathrm{~mm}$ in diameter, which display regular concentric laminae surrounding a central core. These laminae are usually coalesced in group forming zones, which are distinguished by color variation [8].

XRD analysis indicated that hematite is the main iron bearing minerals, whereas quartz, fluorapatite and chamosite are the main gangue minerals Figure 1. XRF analysis of the original sample indicated that $\mathrm{Fe}_{2} \mathrm{O}_{3}$ and $\mathrm{P}_{2} \mathrm{O}_{5}$ grades are $74.96 \%$ and $3.24 \%$ respectively Table $1 . \mathrm{P}_{2} \mathrm{O}_{5}, \mathrm{CaO}$ and $\mathrm{F}$ content are related to fluoroapatite, whereas $\mathrm{Al}_{2} \mathrm{O}_{3}$, $\mathrm{MgO}$ and $\mathrm{MnO}$ content are related to chamosite. $\mathrm{SiO}_{2}$ content related to quartz and chamosite. Optical photomicrograph and SEM images of the high phosphorous iron ores show that Fe-bearing minerals occur as ooiltic hematite Figure 2(A) and Figure 2(F). Fluoroapatite (phosphorus bearing mineral) occur mainly as fine-grained cement-like materials mixed with iron filling the spaces between ooid grains Figure 2(C) and Figure 2(E). Chamosite occurs as rim surrounded the ooid grains Figure 2(C) and Figure 2(D).

\section{Distribution of Phosphorus}

Figure 3 shows element maps made in the ferruginous ooids and spaces between ooids for $\mathrm{Fe}, \mathrm{P}, \mathrm{Ca}, \mathrm{Si}$ and $\mathrm{Al}$. The EDS distribution map of iron shows that iron has higher concentration inside ooids than in the spaces between ooids Figure 3. It can be seen that phosphorus and calcium associated closely (particles with high phosphorus content also contained high calcium content) and concentrated in the spaces between ooids, the distribution of $\mathrm{P}$ and $\mathrm{Ca}$ are related to fluoroapatite Figure 3. This indicates that fluoroapatite concentrated mainly in the interstitial spaces between ooids. Silicon clearly detected in the rim zones around the ooids. The distribution of silicon related to both quartz and chamosite. Aluminum related to chamosite and concentrated mainly around ooids and less concentrated inside ooids.

\subsection{Heating Rate of the Iron Ore}

Different size fractions of iron ore were prepared by crushing and sieving. These fractions are $+8 \mathrm{~mm},-8+4$ 

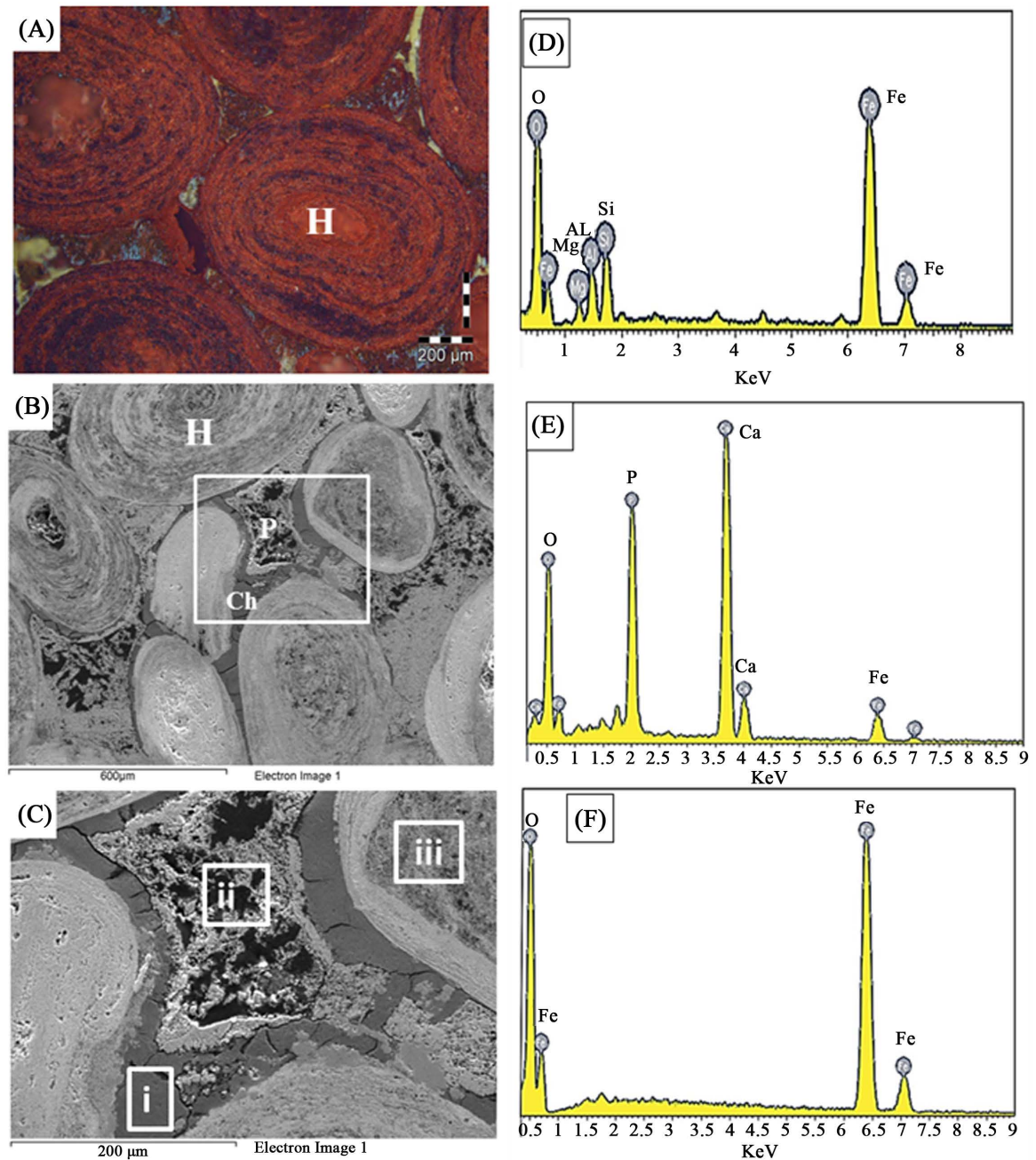

Figure 2. Thin sections and SEM photomicrographs of the high phosphorus oolitic ironstone (A) An optical photomicrograph showing the oolitic iron structure. (B) and (C) SEM photomicrographs showing the matrix between ooids. (D), (E) and (F) EDX analyses of the squared area (i, ii, iii) in Figure 3(C) respectively.
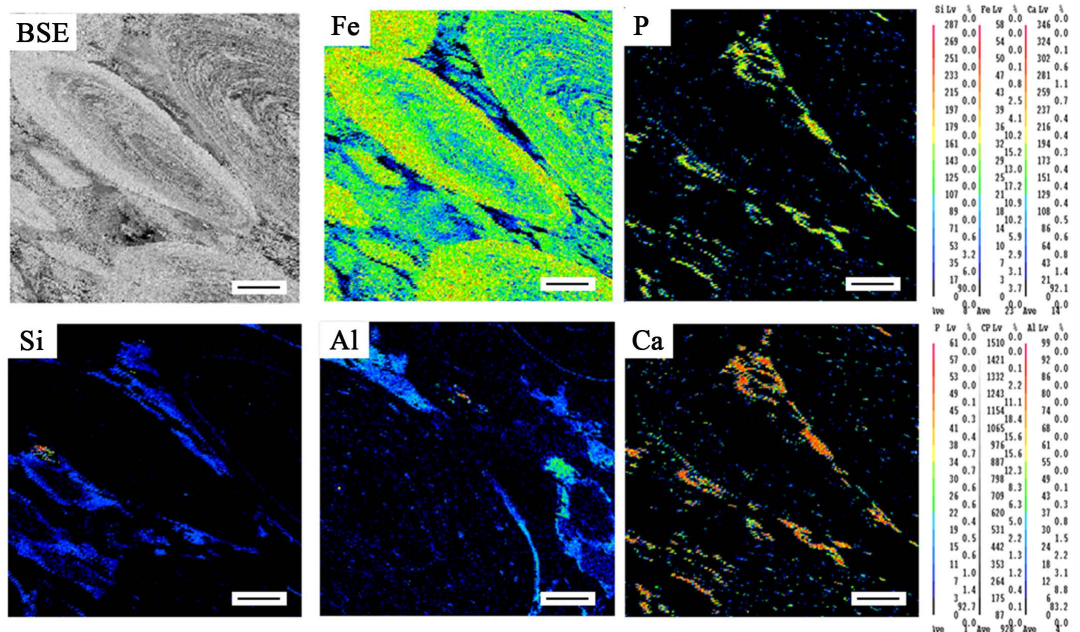

Figure 3. Back-scattered image of the oolitic structure and element maps show the distribution of Fe, P, Si, $\mathrm{Al}$ and $\mathrm{Ca}$ inside oolitic structure and in the matrix between ooides. Scale bar is $100 \mu \mathrm{m}$. 
$\mathrm{mm},-4+2 \mathrm{~mm},-2+1 \mathrm{~mm},-1+0.5 \mathrm{~mm},-0.5+0.25 \mathrm{~mm},-0.25+0.125 \mathrm{~mm},-0.125+0.065 \mathrm{~mm},-0.065+$ $0.032 \mathrm{~mm}$ and $-0.032 \mathrm{~mm}$. 50 grams of representative samples of different size fractions were used in the tests. Samples were placed in the oven in crucible from pure alumina. The crucible was located in the central position. The sample was treated with microwave radiation at different power levels and exposure times. The temperature of the test sample was measured by quickly inserting thermocouple into the sample after the power was turned off and monitored by a digital display temperature controller Figure 4 [34]. The measured temperatures are the bulk temperature of the test sample.

The effects of power density, exposure time and particle size on the temperature of the iron ore were studied.

Figure 5 shows that temperature increases with increasing particle size. For example for a $+8 \mathrm{~mm}$ particle size exposed to a microwave power density of $900 \mathrm{~W}$ for $60 \mathrm{~s}$ the particle temperature is $546^{\circ} \mathrm{C}$ while for the + $0.5-1 \mathrm{~mm}$ particle size under the same conditions the particle temperature is $485^{\circ} \mathrm{C}$. These small size particles are very important in the process flow sheet: as the size decreases it requires more energy to crush and grind. Also higher power densities and exposure times are required for smaller particle sizes to exhibit the same temperature, and subsequent weakening of particle as large particle.

Figure 5 also shows that with increasing exposure time the temperature of the iron particles increases as expected. The longer exposures time the higher particle temperature. At $90 \mathrm{~s}$ exposure time portion of the sample melted, and the measurement of accurate bulk temperature became difficult.

The power density is very important in generation of the temperatures required to thermally damage the rock. Figure 6 indicates that with increasing power density, the temperature of the iron particles increased. For example $+8 \mathrm{~mm}$ particle size exposed to $900 \mathrm{~W}$ power density at $50 \mathrm{~s}$ radiation time the particle temperature is $420^{\circ} \mathrm{C}$,

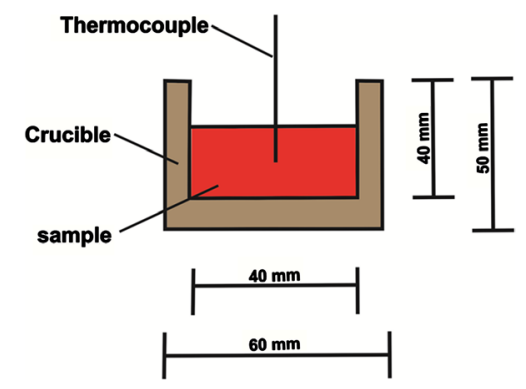

Figure 4. Schematic representation of the crucible and temperature measurement of the sample.

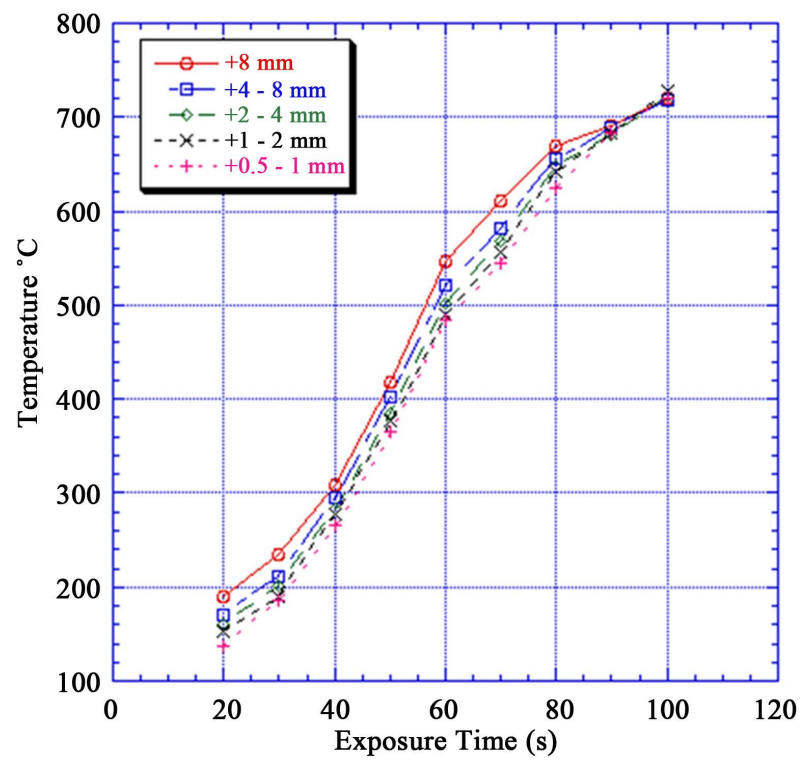

Figure 5. Effect of exposure time on mineral temperature at different particle sizes. 


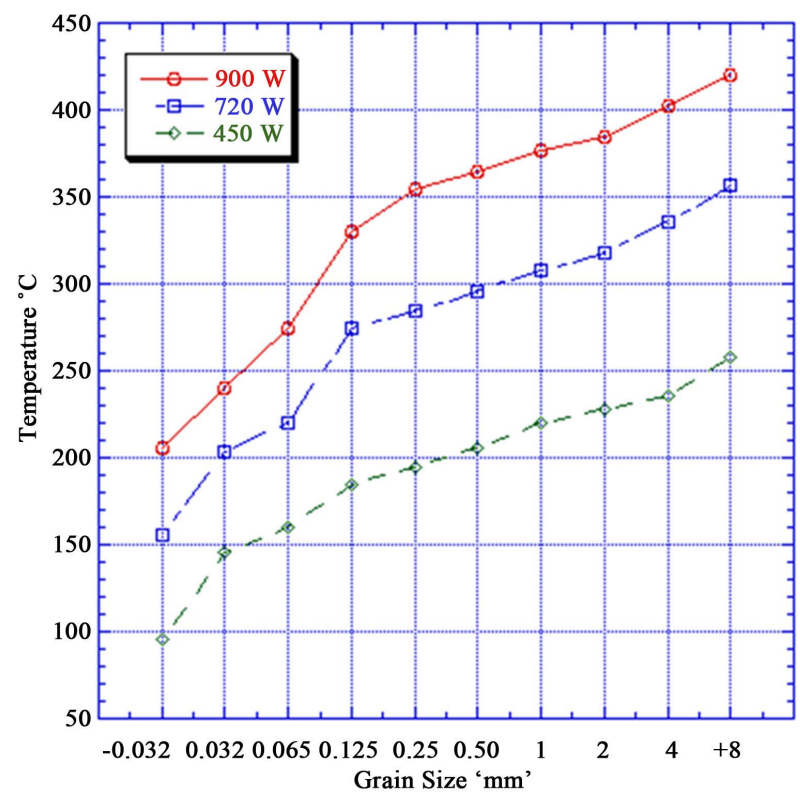

Figure 6. Effect of microwave power density on the mineral temperature (At $50 \mathrm{~s}$ radiation time).

while the same particle size exposed to $450 \mathrm{~W}$ power density for the same exposure time the particle temperature is $258^{\circ} \mathrm{C}$. It can be noted that the power density has a large influence on the temperature and weakening of the iron ores.

Figure 7 shows the XRD analysis of samples before and after microwave treatment. It has been found that the microwave treated sample has peaks sharper than that of untreated. It means the crystallinity increases with increase microwave exposure time, but no phase change. With increasing microwave radiation time, the peak intensity (Crystallinity) of hematite increases. When melting start (at exposure time up to $150 \mathrm{~s}$ ) the peak intensity of hematite decreases. No phase transformation of hematite after microwave heating was detected. Lack of any phase change after microwave treatment has been also noted by Barani et al. [35]. The peaks of chamosite disappear after $50 \mathrm{~s}$ exposure time. At this exposure time temperature of sample exceeds $400^{\circ} \mathrm{C}$ and chamosite decomposed after this temperature and became amorphous.

\subsection{Effect of Microwave Radiation on the Liberation of High Phosphorous Oolitic Iron Ore}

The oolitic iron ore was observed with the SEM before and after microwave treatment. After that, the images at the same area were compared to find the changes of the ore before and after microwave treatment. The influence of power density, exposure time and grain size on the damage and microfracture of the oolitic iron ore were investigated.

As the previous theoretical studies concerning on microwave treatment of ore, the main cause of the damage after microwave treatment is the thermally-induced tensile stresses, which occurred during the thermal expansion of the absorbent phases, exceeding the tensile strength of the material [21] [24] [26] [35]-[37]. Hematite is an active material to microwave heating, while gangues are inactive materials. Table 2 gives the heating properties of hematite and gangues minerals with microwave [38] [39]. It was reported that the microwave heating rates for hematite and quartz were $170^{\circ} \mathrm{C} / \mathrm{s}$ and $2^{\circ} \mathrm{C} / \mathrm{s}$, respectively [23]. When iron ore exposed to microwave radiation, hematite expanded more than quartz this difference on the expanding resulted in the formation of intergranular fractures [9].

Figure 8 SEM images of the oolitic iron ore before and after treatment by microwave radiation. For the short exposure time $40 \mathrm{~s}$ and microwave power of $900 \mathrm{~W}$ microfractures occur in the matrix around the oolites Figure 9(A). With increased exposure time to $50 \mathrm{~s}$ at the same power density these fractures appeared between oolites and matrix (intergranular fractures between oolite and matrix) Figure 9(B). With increased exposure time to 60 $\mathrm{s}$ at microwave power of $900 \mathrm{~W}$, the cracks were more localized around the oolites boundaries and almost no damages in the oolites grains Figure 10. At this stage, oolites are mostly liberated from the matrix which means 


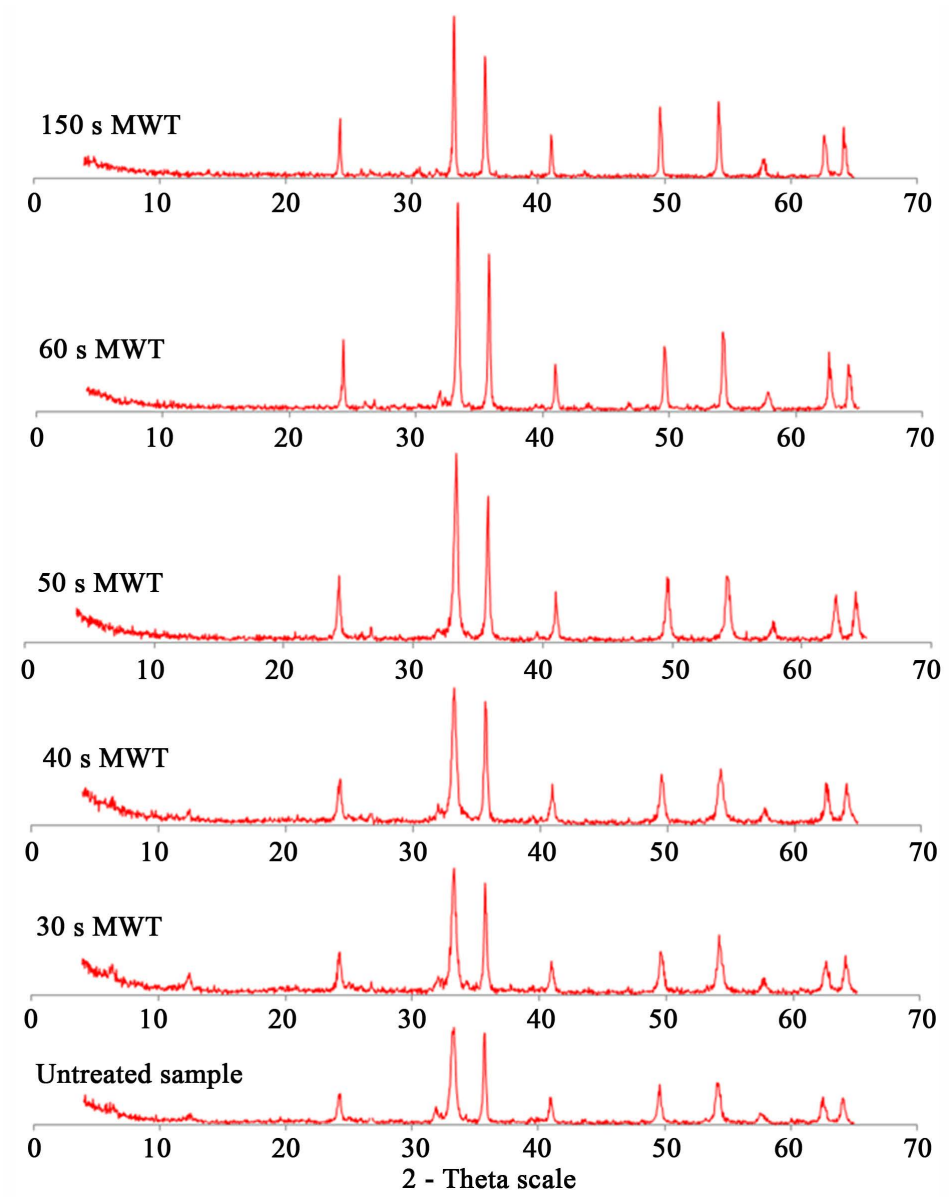

Figure 7. X-ray analysis of microwave treated and untreated samples.
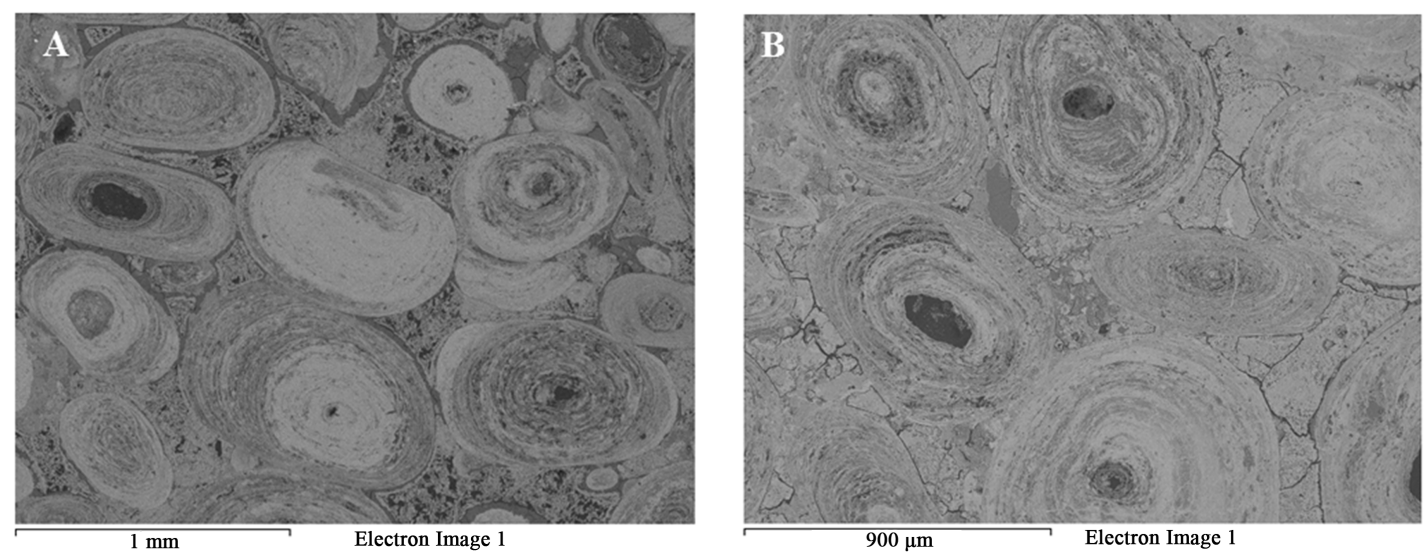

Figure 8. BSE of the Oolitic iron ore (A) Before and (B) After microwave treatment.

Table 2. Heating properties of minerals with microwave radiation.

\begin{tabular}{|c|c|c|}
\hline Mineral & Formula & Microwave heating \\
\hline Hematite & $\mathrm{Fe}_{2} \mathrm{O}_{3}$ & Heat readily, but no mineral phase change (active) \\
\hline Quartz & $\mathrm{SiO}_{2}$ & Does not heat (inactive) \\
\hline Fluroapatite & $\mathrm{Ca}_{5}\left(\mathrm{PO}_{4}, \mathrm{CO}_{3}\right)_{3} \mathrm{~F}$ & Very little or no heat generated \\
\hline Chamosite & $\left(\mathrm{Fe}^{++}, \mathrm{Mg}, \mathrm{Fe}^{+++}\right)_{5} \mathrm{Al}\left(\mathrm{Si}_{3} \mathrm{Al}\right) \mathrm{O}_{10}(\mathrm{OH}, \mathrm{O})_{8}$ & Very little or no heat generated \\
\hline
\end{tabular}



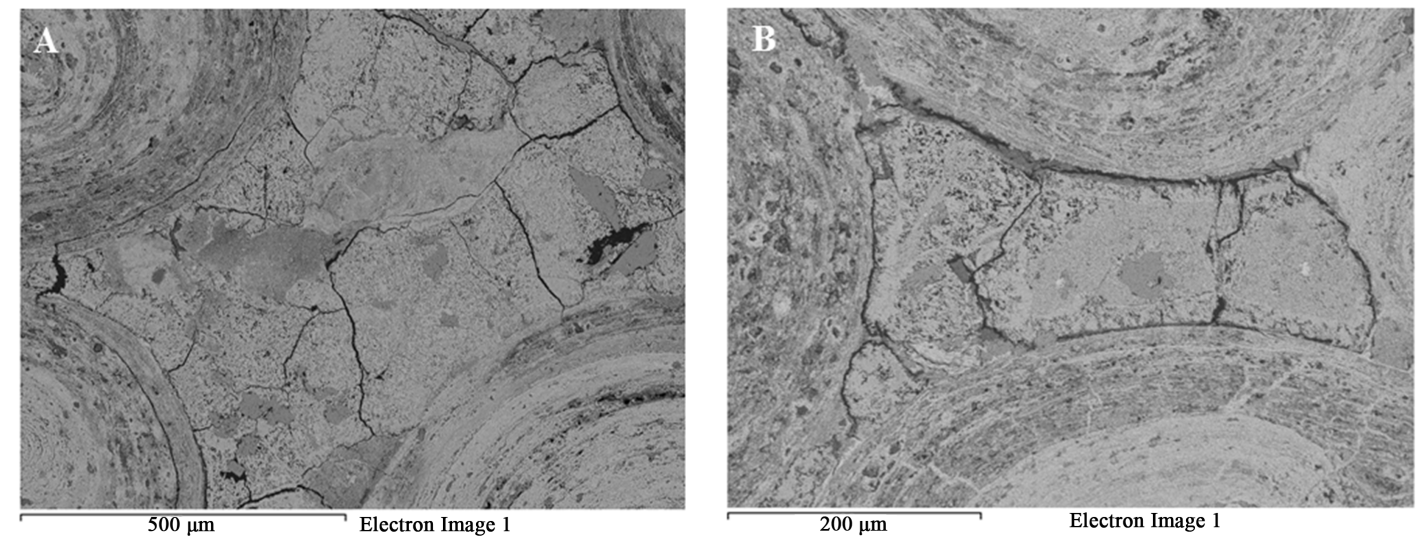

Figure 9. BSE images of the oolitic iron ore after microwave treatment (A) Matrix microfractures; (B) Intergranular fracture between ooids and matrix.

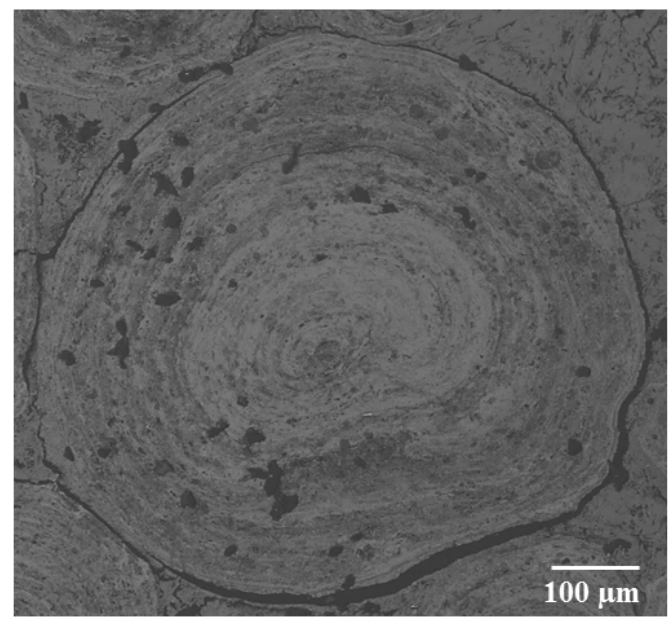

Figure 10. BSE image of completely liberated ooid grain.

that most of phosphorus can be removed Figure 3. These localized damages would effectively facilitate liberation of oolites at coarser size and reduce over grinding and slimes losses. At higher exposure time $80 \mathrm{~s}$ and microwave power of $900 \mathrm{~W}$ intergranular microfractures in the oolitic layers and transgranular fractures in the oolites occurred Figure 11. With increased exposure time up to $90 \mathrm{~s}$ at the same microwave power, part of the sample melted Figure 12. At exposure time up to $150 \mathrm{~s}$ the sample completely melted Figure 13.

It can be concluded that, as the exposure time increases the fractures increases. The microfracture firstly occurs in the matrix, and then by increasing exposure time intergranular oolite/matrix and transgranular fractures in the oolitic structures occurs.

Figure 14 shows the effect of the microwave power density on the formation of microfractures or intergranular oolite/matix boundaries fractures. At the same exposure time, increasing microwave power would increase the heating rate of iron ore Figure 6 and thus the expanding difference between hematite and gangues increased. Figure 14 shows that oolitic iron ore exposed to $900 \mathrm{~W}$ and $450 \mathrm{~W}$ microwave powers for 50 s radiation times, a significant damage was observed for high microwave power, while only few micro-cracks in the matrix occurred in the low microwave power. Lower microwave power required more exposure times to induce the same damages as higher microwave power. Whittles et al. [25] investigated the effect of power density on the microwave treatment of ores and found that the power density is an important factor in microwave treatment of ores. It decreases energy consumption and improves the efficiency.

Figure 15 shows the effect of grain size on the oolites boundaries fractures. The oolitic iron ore of different grain sizes exposed to the same microwave powers and exposure times (at $900 \mathrm{~W}$ microwave power and $60 \mathrm{~s}$ exposure time). Based on SEM observation, as the grain size decreases, the damage incurred in the samples be- 

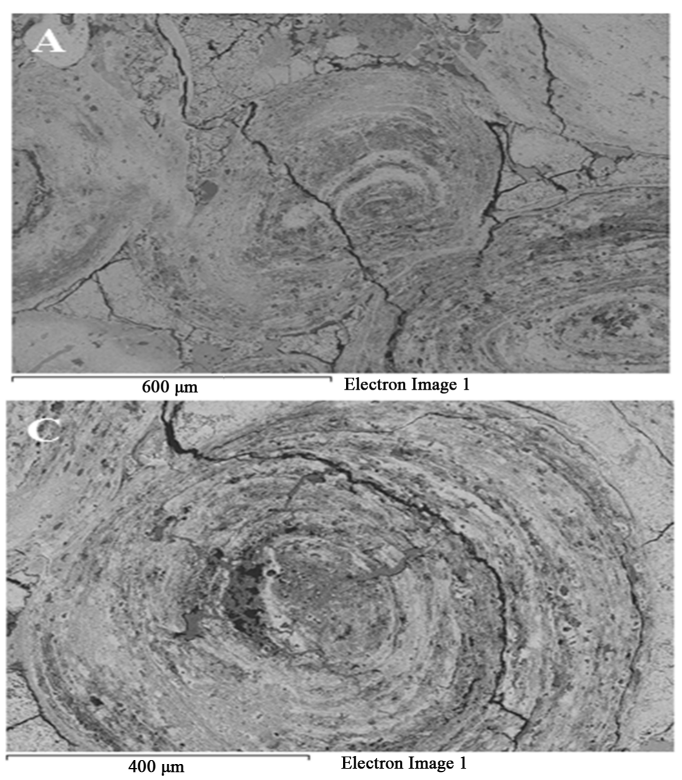

Figure 11. BSE of oolitic iron ore after microwave treatment (A) and (B) Transgranularoolitic fractures; (C) and (D) Intergranular microfractures in oolitic layers.

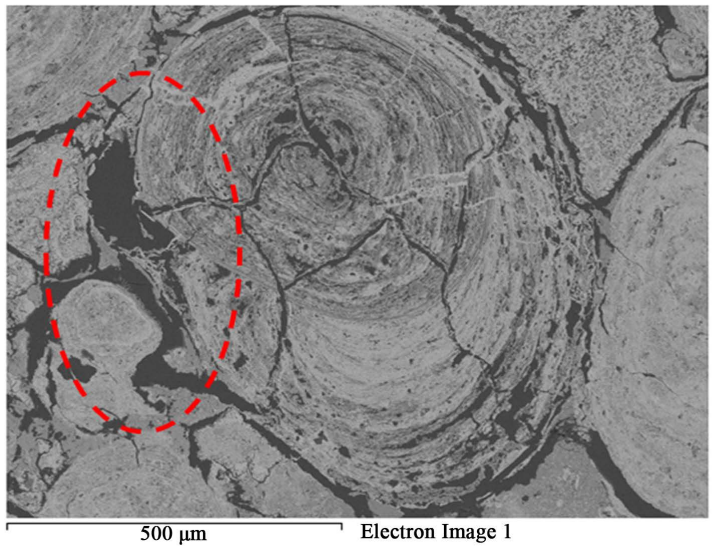

Figure 12. BSE image of microwave treated oolitic iron ore shows that part of the sample was melted.

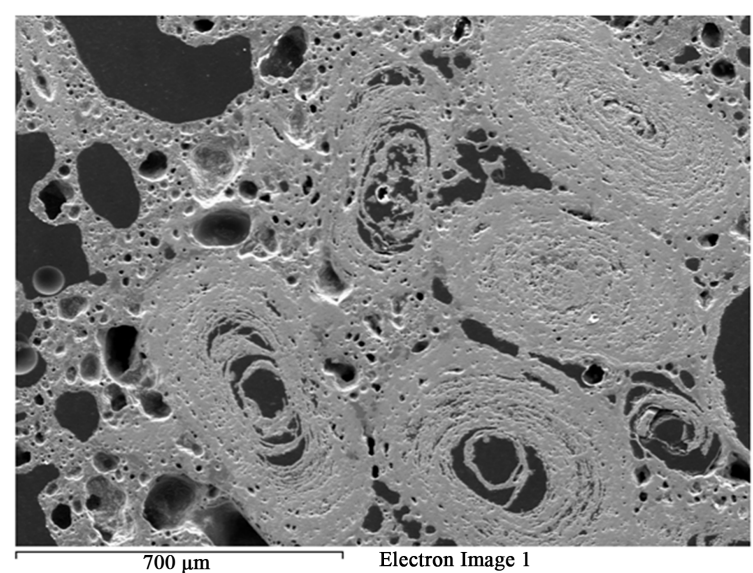

Figure 13. SEM image of the melting oolitic iron ore sample. 

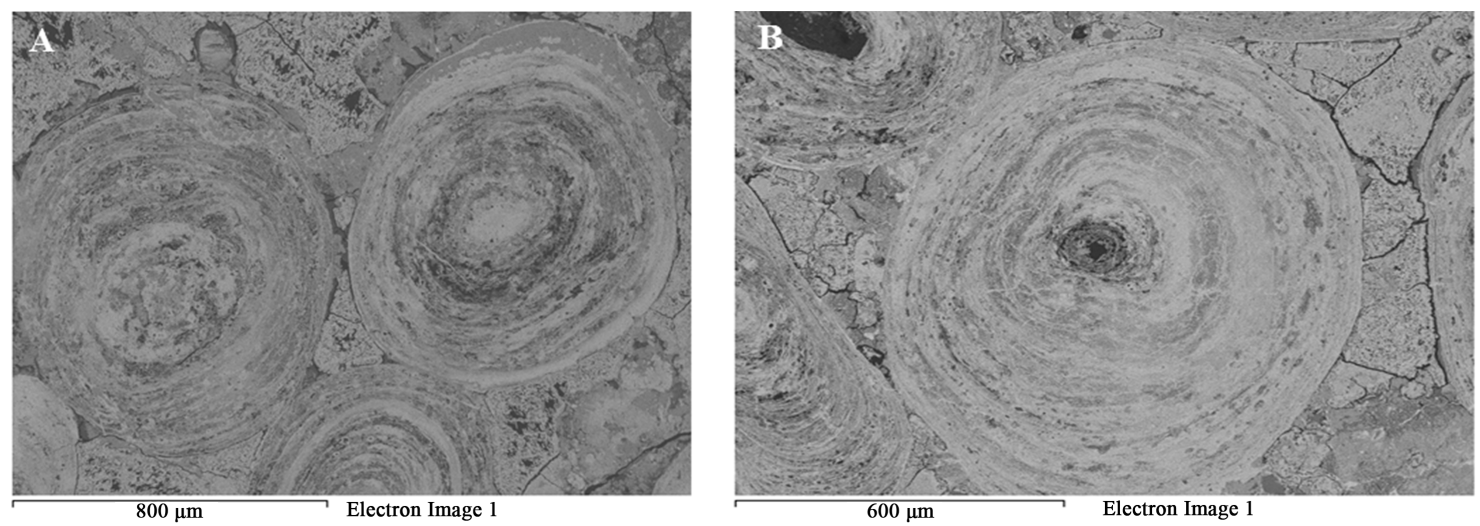

Figure 14. BSE images of oolitic iron ores treated at different microwave powers at $50 \mathrm{~s}$ exposure time. (A) $450 \mathrm{~W}$ power; (B) $900 \mathrm{~W}$.

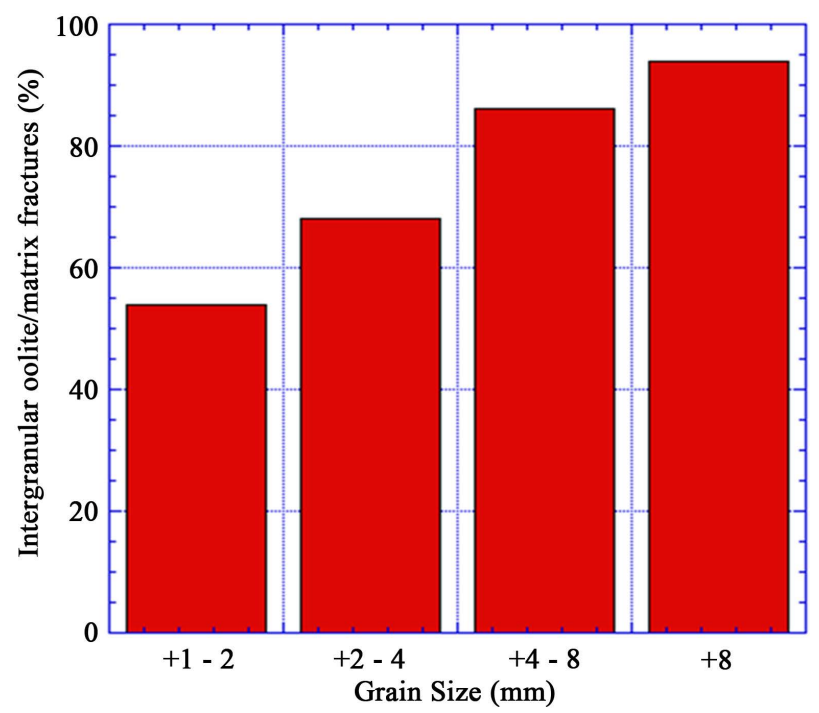

Figure 15. Effect of grain size of the oolitic iron ore on the amount of intergranular oolite/matrix fractures (oolites boundaries damage).

comes lower. Thus a higher energy input is required for the fine grain size to have the same damage as for a coarse grained ore. For example the amount of the ooids boundaries damage for grain sizes $+8 \mathrm{~mm}$ and $+1-2$ $\mathrm{mm}$ are $94 \%$ and $54 \%$ respectively.

\subsection{Grindability Test}

To measure the changes in the grindability of iron ore, the microwave treated and untreated samples were ground for $30 \mathrm{~s} .100$ grams of the crushed ore sample was first treated in the microwave oven for different exposure times 30, 40, 50 and $60 \mathrm{~s}$ at microwave power of $900 \mathrm{~W}$. After grinding, the fraction of less than 0.125 $\mathrm{mm}$ of the ground specimen was determined by sieve analysis for both untreated and microwave-treated iron ore samples.

Then calculate grindability $\%=$ wt of undersize fraction $(0.125) /$ total wt before grinding $\times 100$

Figure 16 shows that the weight percentage of untreated and microwave treated samples for $-0.125 \mathrm{~mm}$ size fractions. It is clear from Figure 16 after $60 \mathrm{~s}$ of microwave pretreatment, the increases in the rate of weight percentages of microwave treated iron ore for $-0.125 \mathrm{~mm}$ particle size to $59.76 \%$, while the weight percent for untreated sample is $46.6 \%$. Microwave radiation displayed more cracks and fractures in iron ores, these fractures occur around the grain boundaries between iron and gangues minerals. A reduction in comminution energy is 


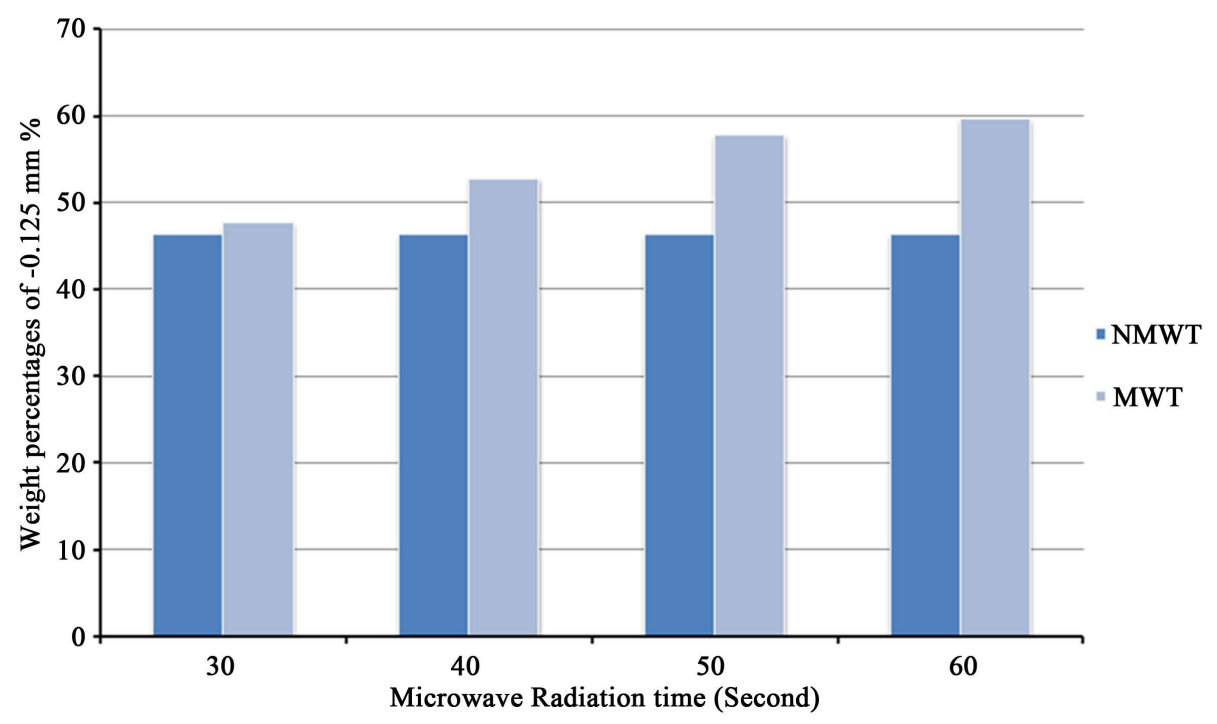

Figure 16. The weight percentage of untreated and microwave treated samples for $-0.125 \mathrm{~mm}$ size fractions.

possible after microwave treatment.

The particles size distribution of microwave treated and untreated samples show that microwave pretreatment have two advantages:

1) Increased grindability of iron;

2) Reduced very fine size (slimes) produced during grinding. The weight percentages of particles less than 32 micron for untreated and microwave treated sample for $60 \mathrm{~s}$ are $1.24 \%$ and $0.48 \%$ respectively. These slimes are not suitable and interfere with physical separation techniques.

\section{Conclusions}

The effect of microwave pretreatment on the liberation of high phosphorus oolitic iron ore has been investigated. According to the experiments:

- SEM analysis indicated that intergranular fractures occurred between oolite and matrix (fluoroapatite and chamosite) after microwave treatment, which facilitated minerals liberation from each other at coarse size. The study showed that liberation and intergranular fractures increased by increasing microwave exposure time and grain size.

- According to the results of heating rate of iron ore, particles size is a very important factor. As the size of the particle decreases, more energy is required to raise the temperature of the particles and subsequent weakening and damage of particles. XRD analyses indicate that the peak intensity of hematite increase with increased exposure time.

- The particles size distributions indicate that microwave pretreatment of oolitic iron ore can be applied effectively to enhance the grindabilty and reduced slime production during grinding of iron ore.

\section{Acknowledgments}

The authors are very much thankful to (Cultural Affair and Mission Sector, Egypt) and CIMO (Center for International Mobility, Finland) for their financial grant to carry out the present research work. The authors are indebted to Prof. Ali Abdelmotelib from geology Department, Cairo University for his assistance during sample collection from Aswan region, Egypt. The authors would like to thank Mr. Riku Mattila and Mr. Tommi Kokkonen for their technical support throughout their work.

\section{References}

[1] Flügel, E. (2010) Microfacies of Carbonate Rocks. Analysis, Interpretation and Application. Springer-Verlag, Berlin. 
[2] Manieh, A.A. (1984) Oolite Liberation of Oolitic Iron Ore, Wadi Fatima, Saudi Arabia. International Journal of Mineral Processing, 13, 187-192. http://dx.doi.org/10.1016/0301-7516(84)90002-4

[3] Champetier, Y., Hamdadou, E. and Hamdadou, M. (1987) Examples of Biogenic Support of Mineralization in Two Oolitic Iron Ores_-Lorraine (France) and Garadjebilet (Algeria). Sedimentary Geology, 51, 249-255. http://dx.doi.org/10.1016/0037-0738(87)90050-9

[4] Ozdemir, O. and Deutsch, E.R. (1984) Magnetic Properties of Oolitic Iron Ore on Bell Island, New Found Land. Earth and Planetary Science Letters, 69, 427-441. http://dx.doi.org/10.1016/0012-821X(84)90201-2

[5] Abro, M.M., Pathan, A.G. and Mallah, A.H. (2011) Liberation of Oolitic Hematite Grains from Iron Ore, Dilband Mines Pakistan. Mehran University Research, Journal of Engineering Technology, 30, 329-338.

[6] Li, K., Ni, W., Zhu, M., Zheng, M. and Li, Y. (2011) Iron Extraction from Oolitic Iron Ore by a Deep Reduction Process. Journal of Iron and Steel Research International, 18, 9-13. http://dx.doi.org/10.1016/S1006-706X(11)60096-4

[7] El Sharkawi, M.A., El Aref, M.M. and Mesaed, A.A. (1996) Stratigraphic setting and Paleoenvironment of the Conician-Santonian Ironstones of Aswan, South Egypt. Geological Society of Egypt, 243-278

[8] El Aref, M.M., El Sharkawi, M.A. and Mesaed, A.A. (1996) Depositional and Diagenetic Microfabric Evolution of the Cretaceous Oolitic Ironstone of Aswan, Egypt. Geological Society of Egypt, 279-312.

[9] Song, S., Campos-Toro, E. F. and Valdivieso, A. L. (2013) Formation of Micro-Fractures on an Oolitic Iron Ore under Microwave Treatment and its Effect on Selective Fragmentation. Journal of Powder Technology, 243, 155-160. http://dx.doi.org/10.1016/j.powtec.2013.03.049

[10] Ji, J. (2003) Study on Dephosphorization Technology for High-Phosphorus Iron Ore. Mining \& Metallurgy. 12 , 33-37.

[11] Xia, W.T., Ren, Z.D. and Gao, Y.F. (2011) Removal of Phosphorus from High Phosphorus Iron Ores by Selective HCl Leaching Method. International Journal of Iron and Steel Research, 18, 1-4. http://dx.doi.org/10.1016/S1006-706X(11)60055-1

[12] Cheng, C.Y., Misra, V.N., Clough, J. and Muni, R. (1999) Dephosphorisation of Western Australian Iron Ore by Hydrometallurgical Process. Minerals Engineering, 12, 1083-1092. http://dx.doi.org/10.1016/S0892-6875(99)00093-X

[13] Wang, J.C., Shen, S.B., Kang, J.H., Li, H.X. and Guo, Z.C. (2010) Effect of Ore Solid Concentration on the Bioleaching of Phosphorus from High-Phosphorus Iron Ores Using Indigenous Sulfur-Oxidizing Bacteria from Municipal Wastewater. Process Biochemistry, 45, 1624-1631.

[14] Delvasto, P., Valverde, A., Ballester, A., Munoz, J.A., Gonzalez, F. and Blazquez, M.L. (2008) Diversity and Activity of Phosphate Bioleaching Bacteria from a High-Phosphorus Iron Ore. Hydrometallurgy, 92, 124-129. http://dx.doi.org/10.1016/j.hydromet.2008.02.007

[15] Yu, Y.F. and Qi, C.Y. (2011) Magnetizing Roasting Mechanism and Effective Ore Dressing Process for Oolitic Hematite Ore. Journal of Wuhan University of Technology. Materials Science Ed., 26, 176-181. http://dx.doi.org/10.1007/s11595-011-0192-6

[16] Tang, H.Q., Guo, Z.C. and Zhao, Z.L. (2010) Phosphorus Removal of High Phosphorus Iron Ore by Gas-Based Reduction and Melt Separation. International Journal of Iron and Steel Research, 17, 1-6. http://dx.doi.org/10.1016/S1006-706X(10)60133-1

[17] Fisher-White, M.J., Lovel, R.R. and Sparrow, G.J. (2012) Phosphorus Removal from Goethitic Iron Ore with a Low Temperature Heat Treatment and a Caustic Leach. ISIJ International, 52, 797-803.

[18] Kumar, P., Sahoo, B.K., De, S., Kar, D.D., Chakraborty, S. and Meikap, B.C. (2010) Iron Ore Grindabilityim-Provement by Microwave Pretreatment. Journal of Industrial and Engineering Chemistry, 16, 805-812. http://dx.doi.org/10.1016/j.jiec.2010.05.008

[19] Tromans, D. (2008) Mineral Comminution: Energy Efficiency Considerations. Minerals Engineering, 21, 613-620. http://dx.doi.org/10.1016/j.mineng.2007.12.003

[20] Wang, E., Shi, F. and Manlapig, E. (2012) Mineral Liberation by High Voltage Pulses and Conventional Comminution with Same Specific Energy Levels. Minerals Engineering, 27-28, 28-36. http://dx.doi.org/10.1016/j.mineng.2011.12.005

[21] Ali, A.Y. and Bradshaw, S.M. (2009) Quantifying Damage around Grain Boundaries in Microwave Treated Ores. Chemical Engineering and Processing: Process Intensification, 48, 1566-1573. http://dx.doi.org/10.1016/j.cep.2009.09.001

[22] Roussy, G. and Pearce, J.A. (1995) Foundations and Industrial Applications of Microwave and Radiofrequency Fields-Physical and Chemical Processes, Chapters 10, 11, 12. Wiley, Hoboken.

[23] Haque, K.E. (1999) Microwave Energy for Mineral Treatment Processes-A Brief Review. International Journal of Mineral Processing, 57, 1-24. http://dx.doi.org/10.1016/S0301-7516(99)00009-5

[24] Jones, D.A., Kingman, S.W., Whittles, D.N. and Lowndes, I.S. (2005) Understanding Microwave Assisted Breakage. 
Minerals Engineering, 18, 659-669. http://dx.doi.org/10.1016/j.mineng.2004.10.011

[25] Whittles, D.N., Kingman, S.W. and Reddish, D.J. (2003) Application of Numerical Modelling for Prediction of the Influence of Power Density on Microwave-Assisted Breakage. International Journal of Mineral Processing, 68, 71-91. http://dx.doi.org/10.1016/S0301-7516(02)00049-2

[26] Jones, D.A., Kingman, S.W., Whittles, D.N. and Lowndes, I.S. (2007) The Influence of Microwave Energy Delivery Method on Strength Reduction in Ore Samples. Chemical Engineering and Processing: Process Intensification, 46, 291-299. http://dx.doi.org/10.1016/j.cep.2006.06.009

[27] Fitzgibbon, K. and Veasey, T. (1990) Thermally Assisted Liberation-A Review. Minerals Engineering, 3, 181-185. http://dx.doi.org/10.1016/0892-6875(90)90090-X

[28] Kingman, S.W. and Rowson, S.A. (1998) Microwave Treatment of Minerals-A Review. Minerals Engineering, 11, 1081-1087. http://dx.doi.org/10.1016/S0892-6875(98)00094-6

[29] Tang, H.Q., Wang, J.W., Guo, Z. and Ou, T. (2013) Intensifying Gaseous Reduction of High Phosphorus Iron Ore Fines by Microwave Pretreatment. International Journal of Iron and Steel Research, 20, 17-23. http://dx.doi.org/10.1016/S1006-706X(13)60091-6

[30] Amankwah, R.K., Khan, A.U., Pickles, C.A. and Yen, W.T. (2005) Improved Grindability and Gold Liberation by Microwave Pretreatment of a Free Milling Gold Ore. Mineral Processing and Extractive Metallurgy, 114, 30-36. http://dx.doi.org/10.1179/037195505X28447

[31] Kingman, S.W., Corfield, G. and Rowson, N.A. (1999) Effect of Microwave Radiation upon the Mineralogy and Magnetic Processing of a Massive Norwegian Ilmenite. Magnetic and Electrical Separation, 9, 131-148.

[32] Kingman, S.W. and Rowson, N.A. (2000) The Effect of Microwave Radiation on the Magnetic Properties of Minerals. Journal of Microwave Power and Electromagnetic Energy, 35, 141-150.

[33] Kingman, S.W., Vorster, W. and Rowson, N.A. (2000) The Influence of Mineralogy on Microwave Assisted Grinding. Minerals Engineering, 13, 313-327. http://dx.doi.org/10.1016/S0892-6875(00)00010-8

[34] Aguilar-Garib, J.A. (2011) Thermal Microwave Processing of Materials. In: Grundas, S., Ed., Advances in Induction and Microwave Heating of Mineral and Organic Materials, InTech. http://www.intechopen.com/books/advances-in-induction-and-microwaveheating-of-mineral-and-organic-materials/the rmal-microwave-processing-of-materials

[35] Barani, K., Koleini, S.M.J. and Rezaei, B. (2011) Magnetic Properties of an Iron Ore Sample after Microwave Heating. Separation and Purification Technology, 76, 331-336. http://dx.doi.org/10.1016/j.seppur.2010.11.001

[36] Ali, A.Y. and Bradshaw, S.M. (2010) Bonded Particle Modelling of Microwave Induced Damage in Ore Particles. Minerals Engineering, 23, 780-790. http://dx.doi.org/10.1016/j.mineng.2010.05.019

[37] Salsman, J.B., Williamson, R.L., Tolley, W.K. and Rice, D.A. (1996) Short Pulse Microwave Treatment of Disseminated Sulphide Ores. Minerals Engineering, 9, 43-54. http://dx.doi.org/10.1016/0892-6875(95)00130-1

[38] Chen, T.T., Dutrizac, J.E., Haque, K.E., Wyslouzil, W. and Kashyap, S. (1984) The Relative Transparency of Minerals to Microwave Radiation. Canadian Metallurgical Quarterly, 23, 349-351. http://dx.doi.org/10.1179/cmq.1984.23.3.349

[39] Kobusheshe, J. (2010) Microwave Enhanced Processing of Ores. Ph.D. Thesis, the University of Nottingham, Nottingham. 
Scientific Research Publishing (SCIRP) is one of the largest Open Access journal publishers. It is currently publishing more than 200 open access, online, peer-reviewed journals covering a wide range of academic disciplines. SCIRP serves the worldwide academic communities and contributes to the progress and application of science with its publication.

Other selected journals from SCIRP are listed as below. Submit your manuscript to us via either submit@scirp.org or Online Submission Portal.
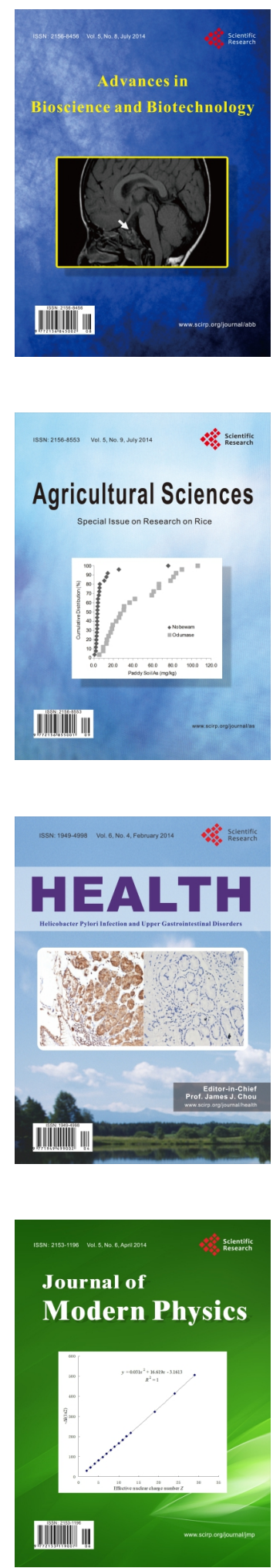
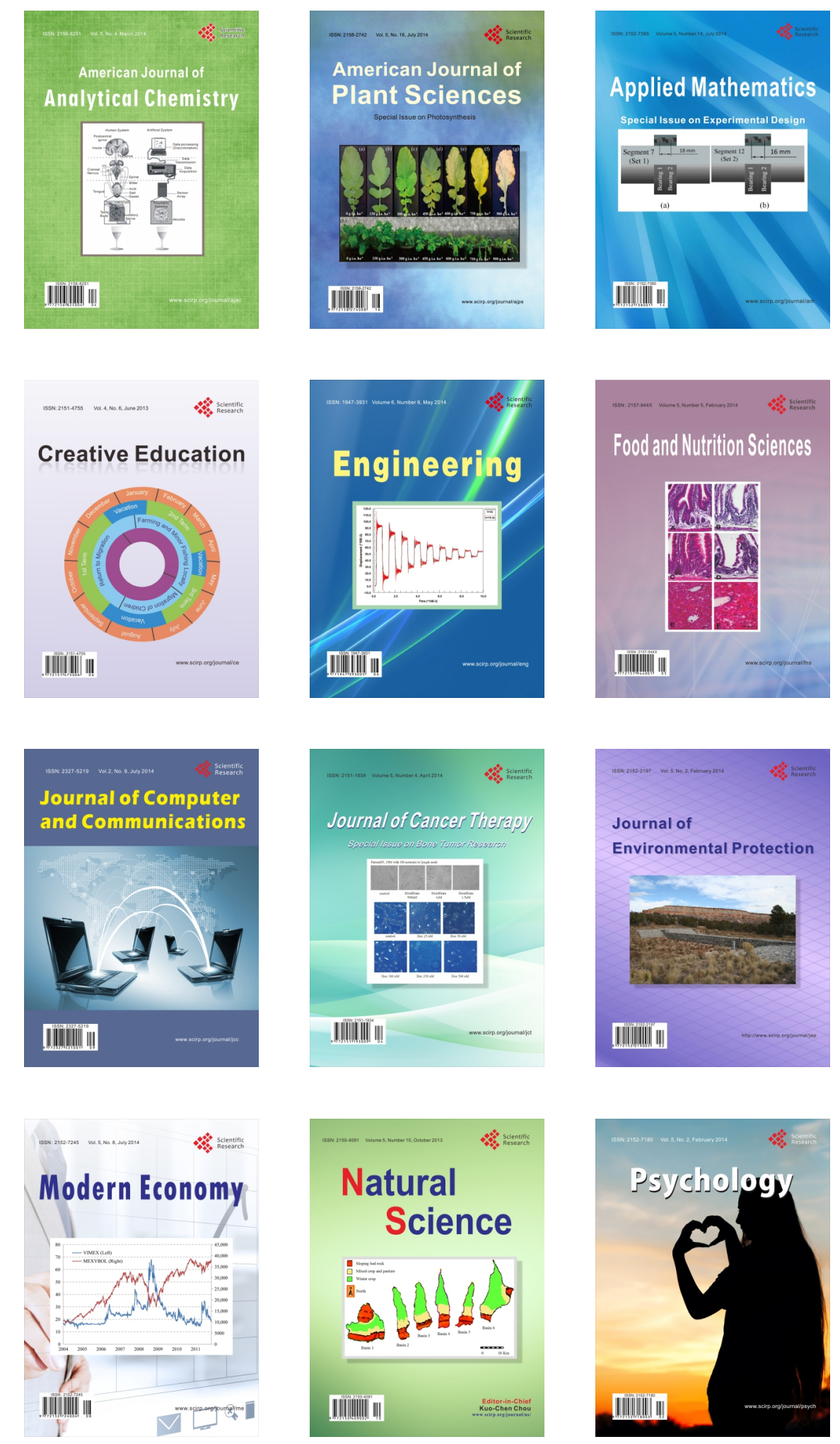